\title{
EXTRACTION AND AMS RADIOCARBON DATING OF POLLEN FROM LAKE BAIKAL SEDIMENTS
}

\author{
Natalia Piotrowska ${ }^{1,2} \cdot$ Andrzej Bluszcz $^{1}$ - Dieter Demske ${ }^{3}$ Wojciech Granoszewski ${ }^{4}$ \\ Georg Heumann ${ }^{5}$
}

\begin{abstract}
This work focuses on the preparation and dating of sporomorph (pollen and spores) concentrates of high purity. Three sediment cores recovered from Lake Baikal within the EU-Project CONTINENT were subjected to palynological analyses and accelerator mass spectrometry (AMS) radiocarbon dating. Laboratory processing of concentrates was aimed at the removal of non-sporomorph organic matter by means of chemical treatment, micro-sieving, and heavy liquid separation. The obtained concentrates were checked under the microscope and sample purity was estimated on the basis of particle counts. The results of AMS ${ }^{14} \mathrm{C}$ dating show differences in the sedimentation rate among 3 sites of Lake Baikal.
\end{abstract}

\section{METHODS}

Lake Baikal is situated in southeast Siberia in the eastern part of the Russian Federation near the Mongolian border. It is the largest ( $20 \%$ of the total volume of surface freshwater), deepest $(>1600 \mathrm{~m}$ ), and probably oldest (about 25 million yr) lake on Earth.

Radiocarbon dating of Lake Baikal sediments is a difficult challenge, as previous studies have proved (Coleman 1996). The main problem is the scarcity of material suitable for dating because the sediments are very poor in organic matter and carbonates. Our work focused on the preparation and dating of high-purity sporomorph concentrates.

Three sediment cores recovered from Lake Baikal were subjected to palynological analyses and AMS ${ }^{14} \mathrm{C}$ dating. The cores come from 3 different locations: Posolskoe Bank, Vydrino Shoulder, and Continent Ridge (see Figure 1). The cores subjected to dating were collected with the use of a Kasten corer, which gives the best assurance of complete recovery of the sediment.

The preliminary knowledge about sporomorph concentrations and sporomorph assemblages in Holocene and Late Glacial core sections, necessary for selecting appropriate subsampling levels, was gained during palynological analyses of these cores. Sample sizes ranged between 20 and $160 \mathrm{~cm}^{3}$ (see Table 1), depending on available material, pollen concentrations, and a rough calculation of pollen mass and carbon content using data available from previous studies (Erdtman 1969; Brown et al. 1989). The volume of samples taken for preparation was adjusted to obtain a minimum carbon content of about 2-4 mg per sample.

\section{Extraction of Sporomorphs}

Laboratory processing of pollen and spore concentrates was aimed at achieving a high purity of the samples. The removal of inorganic and non-sporomorph organic matter was carried out using chemical treatment, micro-sieving, and heavy liquid separation.

\footnotetext{
${ }^{1}$ Silesian University of Technology, Institute of Physics, Department of Radioisotopes, Krzywoustego 2, PL-44-100 Gliwice, Poland.

${ }^{2}$ Corresponding author. Email: natalia.piotrowska@carbon14.pl.

${ }^{3}$ FU Berlin, Institute of Geological Sciences (Palaeontology), Malteserstr. 74-100, D-12249 Berlin, Germany.

${ }^{4}$ Polish Geological Institute, Carpathian Branch, Skrzatów 1, PL-31-560 Kraków, Poland.

Also: W. Szafer Institute of Botany, PAN, Lubicz 46, PL-31-512 Kraków, Poland.

${ }^{5}$ University Bonn, Institute of Palaeontology, Nussallee 8, D-53115 Bonn, Germany.
}

(C) 2004 by the Arizona Board of Regents on behalf of the University of Arizona

Proceedings of the 18th International Radiocarbon Conference, edited by N Beavan Athfield and R J Sparks

RADIOCARBON, Vol 46, Nr 1, 2004, p 181-187 


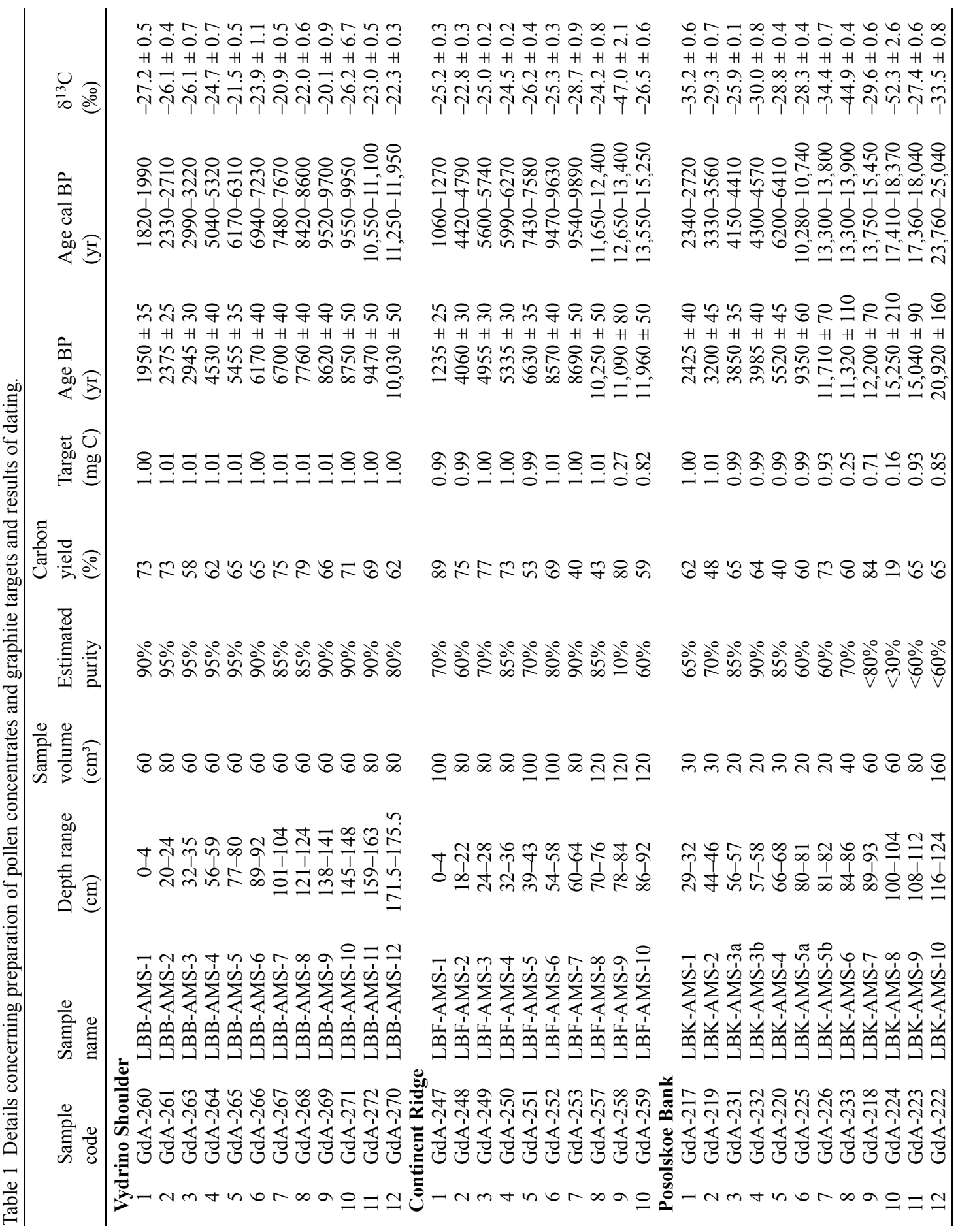




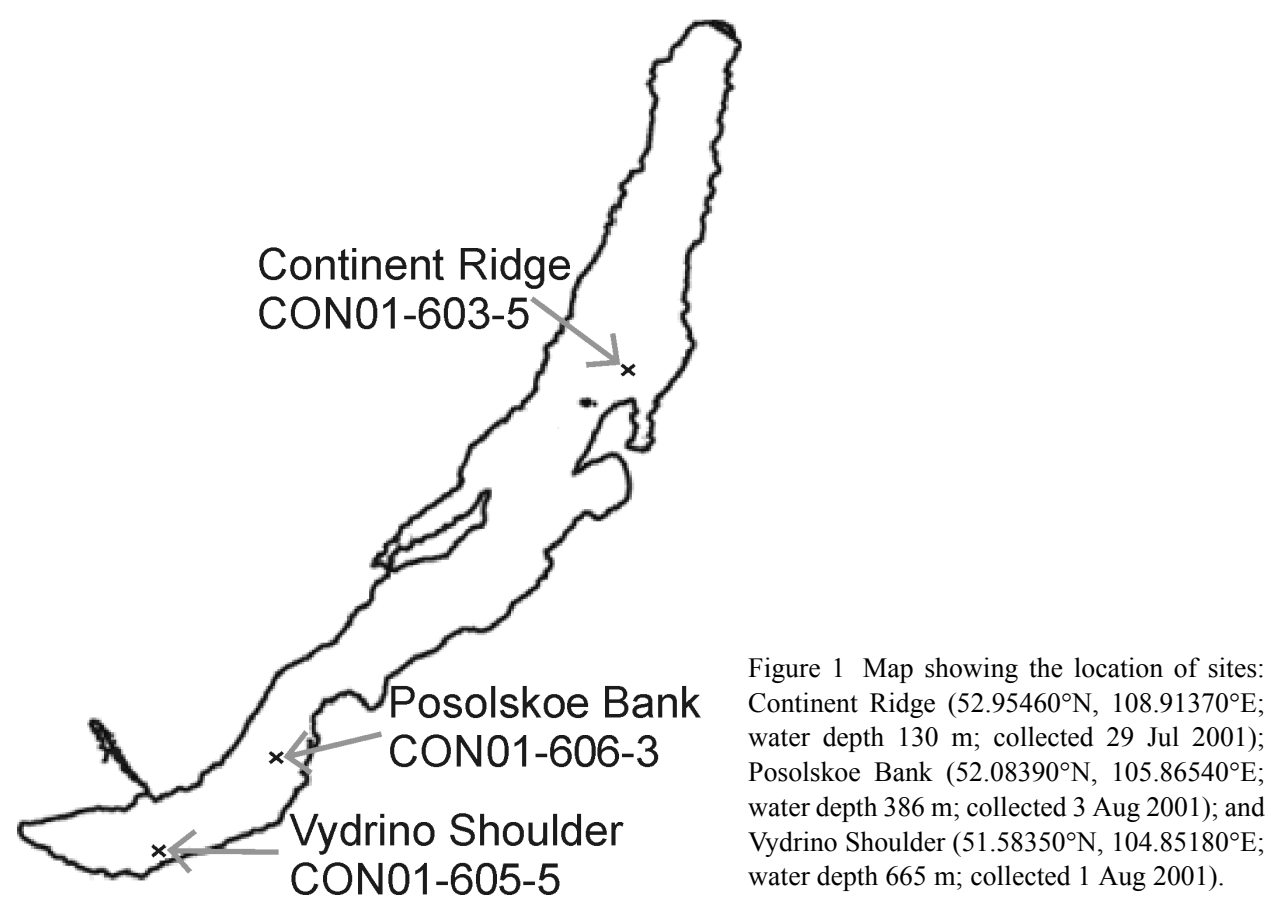

The proposed treatment steps generally follow techniques used by Brown et al. (1989), Regnéll (1992), Regnéll and Everitt (1996), and Nakagawa et al. (1998), but include a modification in specific gravity and a final acid-alkali-acid treatment combined with $10 \mu \mathrm{m}$ micro-sieving. Heavy liquid separation combined with fine- and micro-sieving can provide pure sporomorph samples (Zhou et al. 1997; Morgenroth 2000). The steps for preparation of sporomorph concentrates are presented in Figure 2. The resulting sporomorph concentrate consists of grains of $10-90 \mu \mathrm{m}$ in diameter, with a density of $1.13-1.66 \mathrm{~g} / \mathrm{cm}^{3}$.

\section{Sample Purity Control}

The obtained concentrates were checked under the microscope and photographed (see Figure 3 for a photo example), and sample purity was estimated on the basis of particle counts. Pollen and spore spectra of the concentrates were generally similar to those obtained during standard pollen analysis. However, due to the additionally required chemical (hydrolysis, bleaching) and physical processing steps, some small and delicate pollen types (especially Alnus fruticosa) were partly lost. Organic matter, which could be removed from the sporomorph samples only in part, was comprised of lignin (conifer wood fragments), small globose limnic microfossils, and hyaline particles. For quantification of sample purity, the number of pollen and spores was related to the overall count of organic particles present in the concentrates. By estimation, the resulting purity was slightly adjusted according to the relative size of recorded non-sporomorph organic particles in comparison to pollen grain. Table 1 contains the estimated purity for all the samples. The best sample purity was obtained for the Vydrino core CON01-605-5 due to very high concentrations of large bisaccate pollen grains in the sediment. 

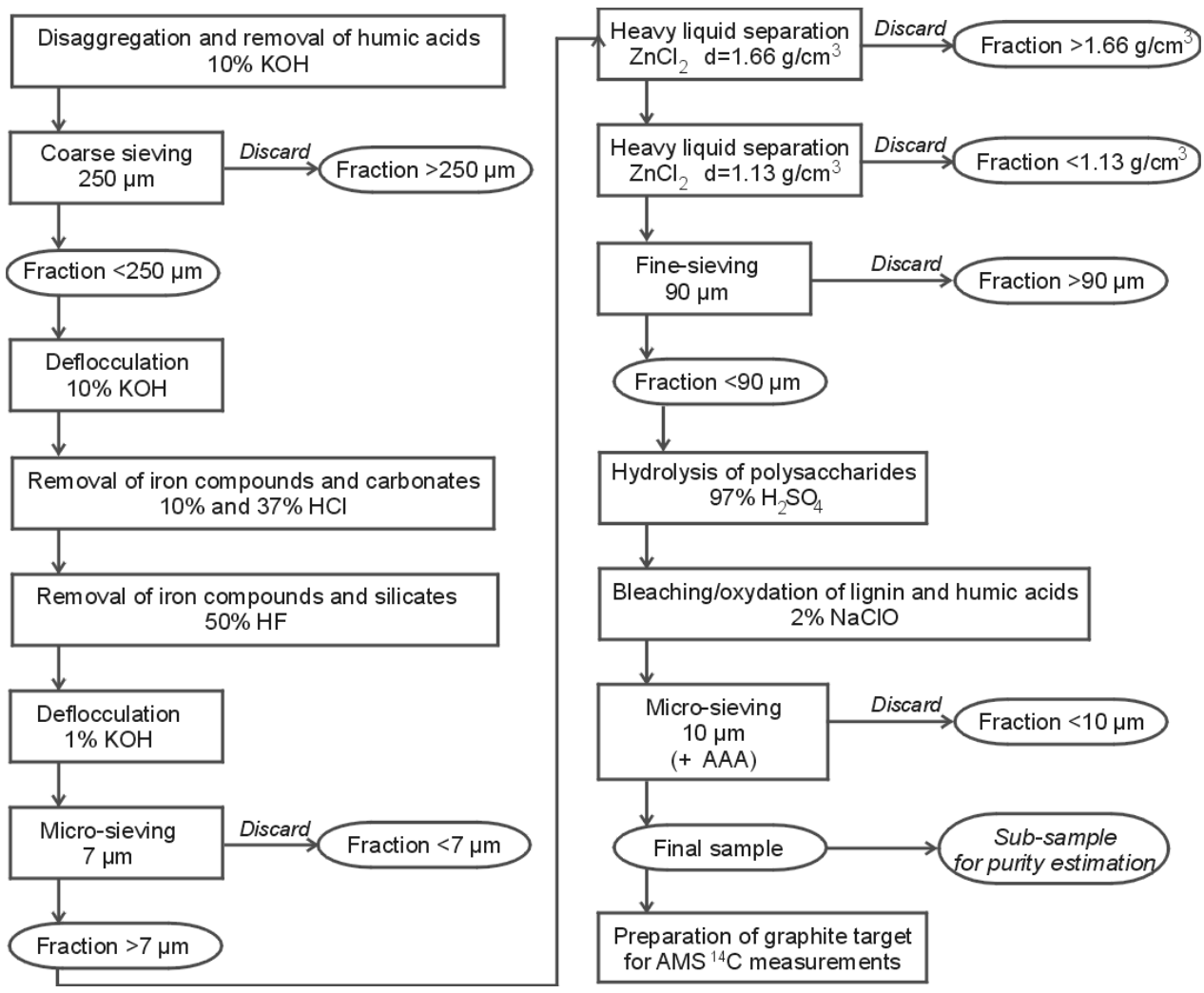

Figure 2 Flow-chart for preparation of sporomorph concentrates

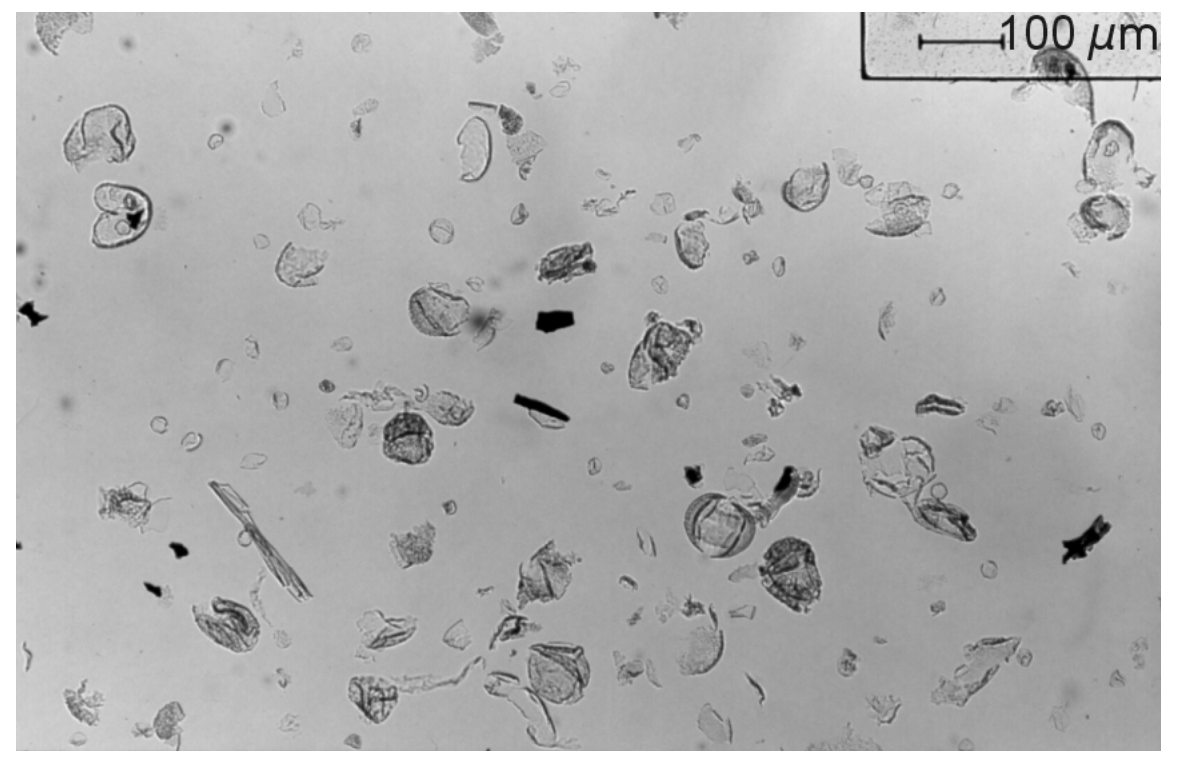

Figure 3 Photo documentation, sample LBF-AMS-8 


\section{Preparation of Graphite Targets for AMS ${ }^{14} \mathrm{C}$ Dating}

The extracts were prepared for AMS measurement in the Gliwice Radiocarbon Laboratory according to the procedures described in Goslar and Czernik (2000) and Czernik and Goslar (2001). The concentration of ${ }^{14} \mathrm{C}$ in produced graphite targets was measured in the Poznań Radiocarbon Laboratory (Goslar et al., forthcoming).

\section{RESULTS AND DISCUSSION}

Details concerning sample preparation and results are given in Table 1. Most of the samples yielded $\mathrm{CO}_{2}$ in amount corresponding to 1 or more $\mathrm{mg}$ of carbon, enabling the preparation of standard AMS targets. The average carbon content in pollen grains (about 64\%) is in accordance with an assumed value (Erdtman 1969; Brown et al. 1989). Additionally, when the amount of $\mathrm{CO}_{2}$ was sufficient, stable carbon isotope measurements were carried out in the Mass Spectrometry Laboratory of the Maria Curie-Sklodowska University in Lublin. The results of stable isotope measurements are within the range of values typical for terrestrial matter.

The ${ }^{14} \mathrm{C}$ ages of pollen samples were calibrated using the OxCal program (Bronk Ramsey 2001) and INTCAL98 calibration curve (Stuiver et al. 1998), except the last 3 dates from Posolskoe Bank (LBK). These dates were beyond the INTCAL98 curve and calibration was performed using the CalPal program and CalPal 2001 curve (Weninger et al. 2003; Jöris and Weninger 1998). For the construction of timescales, the ranges of calibrated ages obtained for 2 confidence intervals were taken, and the centers of the probability distribution ranges were taken as point-estimates for linear regression calculations. For 2 dates of the Posolskoe Bank (LBK-AMS-5a and b), we could have narrowed down the obtained ranges by applying the calibration of an ordered sequence of ${ }^{14} \mathrm{C}$ dates (using OxCal), taking into consideration the stratigraphic order of samples. A similar procedure could be applied to samples LBK-AMS- 8 to 10 , but it seems not justified at this time because the INTCAL98 calibration curve does not cover this time interval. However, we believe that the new officially accepted curve would help to solve this problem.

The results obtained for Continent Ridge and Vydrino Shoulder show a high linear correlation and were used for estimating the average sedimentation rates (Figure 4a,b). The ages of Posolskoe Bank samples are more scattered, indicating the disturbances in the sedimentation process. Two periods of sedimentation were distinguished for which the average sedimentation rates were estimated (Figure 4c). The sedimentological studies, which are still in process, will enable the recognition of possible sedimentation disturbances.

For all 3 sites, a shift in obtained sediment ages can be noticed, resulting in a non-zero age for surface sediment. Various reasons for this effect can be considered. The most likely reason is an incomplete recovery of the core (i.e. with the topmost layer missing), but the other ones also have to be considered. The surface age effect seems to be a complex problem caused by more than 1 reason. A similar effect was observed in previous studies of Lake Baikal sediments (Coleman et al. 1996; Horiuchi et al. 2000), using AMS ${ }^{14} \mathrm{C}$ dating carried out on the total organic carbon (TOC) fraction. Extraction of pollen grains was undertaken in the hope of eliminating this effect, and because macrofossils are extremely rare in Lake Baikal sediments. However, the effect of inconsistent older ages obtained on pollen extracts was observed in other studies, such as the Lake Gościąz sediments (Kilian et al. 2002), which may lead to the conclusion that this could result from specific properties of pollen grains. The surface age effect will be investigated in further studies, and the dating of more samples from the uppermost core sections and from material suspended in water is planned. We hope that this will enable the creation of reliable timescales for the sedimentation process. 


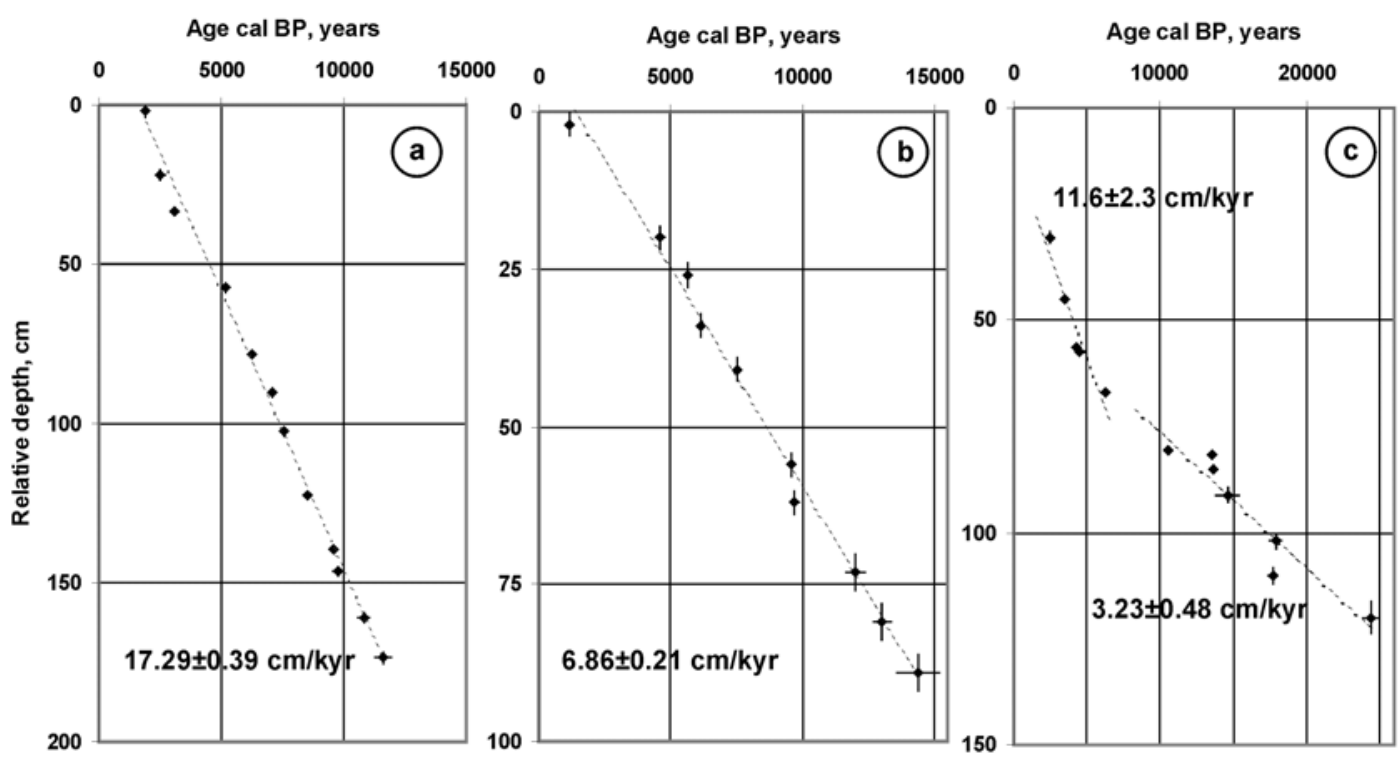

Figure 4 Calibrated age of samples versus depth for 3 investigated cores (a-Vydrino, b-Continent, c-Posolskoe). The vertical error bars represent the depth range and horizontal bars represent the range of calibrated ages. The average sedimentation rates based on linear regression are given in the graphs.

\section{ACKNOWLEDGEMENTS}

The presented work was performed as part of the European Commission project EVK2-CT-200000057 “CONTINENT: High-resolution continental palaeoclimate record in the Lake Baikal: A keysite for Eurasian teleconnections to the North Atlantic Ocean and monsoonal systems."

\section{REFERENCES}

Bronk Ramsey C. 2001. Development of the radiocarbon program OxCal. Radiocarbon 43(2A):355-63.

Brown TA, Nelson DE, Mathewes RW, Vogel JS, Southon JR. 1989. Radiocarbon dating of pollen by accelerator mass spectrometry. Quaternary Research 32: 205-12.

Coleman SM, Jones GA, Rubin M, King JW, Peck JA, Orem WH. 1996. AMS radiocarbon analyses from Lake Baikal, Siberia: challenges of dating sediments from a large, oligotrophic lake. Quaternary Science Reviews 15:669-84.

Czernik J, Goslar T. 2001. Preparation of graphite targets in the Gliwice Radiocarbon Laboratory for AMS ${ }^{14} \mathrm{C}$ dating. Radiocarbon 43(2A):283-91.

Erdtman G. 1969. Handbook of Palynology: Morphology - Taxonomy - Ecology, An Introduction to the Study of Pollen Grains and Spores. Copenhagen: Munksgaard. $486 \mathrm{p}$.

Goslar T, Czernik J. 2000. Sample preparation in the Gliwice Radiocarbon Laboratory for AMS ${ }^{14} \mathrm{C}$ dating of sediments. Geochronometria 18:1-8.

Goslar T, Czernik J, Goslar E. Forthcoming. Low-energy
${ }^{14} \mathrm{C}$ AMS in Poznań Radiocarbon Laboratory. Nuclear Instruments and Methods in Physics Research B.

Horiuchi K, Minoura K, Hoshino K, Oda T, Nakamura T, Kawai T. 2000. Palaeoenvironmental history of Lake Baikal during the last 23000 years. Palaeogeography, Palaeoclimatology, Palaeoecology 157:95-108.

Jöris O, Weninger B. 1998. Extension of the ${ }^{14} \mathrm{C}$ calibration curve to ca. 40,000 cal $\mathrm{BC}$ by synchronizing Greenland ${ }^{18} \mathrm{O} /{ }^{16} \mathrm{O}$ ice core records and North Atlantic foraminifera profiles: a comparison with U/Th coral data. Radiocarbon 40(1):495-504.

Kilian MR, van der Plicht J, van Geel B, Goslar T. 2002. Problematic ${ }^{14} \mathrm{C}$-AMS dates of pollen concentrates from Lake Gościąż (Poland). Quaternary International 88(1):21-6.

Morgenroth G, Kerscher H, Kretschmer W, Klein M, Reichel M, Tully T, Wrzosok I. 2000. Improved sample preparation techniques at the Erlangen AMS Facility. Nuclear Instruments and Methods B 172:416-23.

Nakagawa T, Brugiapaglia E, Digerfeldt G, Reille M, de Beaulieu J-L, Yasuda Y. 1998. Dense-media separation as a more efficient pollen extraction method for 
use with organic sediment/deposit samples: comparison with the conventional methods. Boreas 27:15-24.

Regnéll J. 1992. Preparing pollen concentrates for AMS dating - a methodological study from a hard-water lake in southern Sweden. Boreas 21:373-7.

Regnéll J, Everitt E. 1996. Preparative centrifugation-a new method for preparing pollen concentrates for radiocarbon dating by AMS. Vegetation History and Archaeobotany 5:201-5.

Stuiver M, Reimer PJ, Bard E, Beck JW, Burr GS
Hughen KA, Kromer B, McCormac G, van der Plicht J, Spurk M. 1998. INTCAL98 radiocarbon age calibration, 24,000-0 cal BP. Radiocarbon 40(3):1041-83 Weninger B, Jöris O, Danzeglocke U. 2003. Climate archaeology with Fortran. Fortran Source 19(1) Spring 2003. Lahey Computer Systems, Inc.

Zhou WJ, Donahue D, Jull AJT. 1997. Radiocarbon AMS dating of pollen concentrated from eolian sediments: implications for monsoon climate change since the Late Quaternary. Radiocarbon 39(1):19-26. 